\title{
Investigating the management potential of a seagrass model through sensitivity analysis and experiments
}

\author{
P Fong \\ ME Jacobson \\ MC Mescher \\ D Lirman \\ MC Harwell \\ Virginia Institute of Marine Science
}

Follow this and additional works at: https://scholarworks.wm.edu/vimsarticles

Part of the Ecology and Evolutionary Biology Commons

\section{Recommended Citation}

Fong, P; Jacobson, ME; Mescher, MC; Lirman, D; and Harwell, MC, "Investigating the management potential of a seagrass model through sensitivity analysis and experiments" (1997). VIMS Articles. 1744. https://scholarworks.wm.edu/vimsarticles/1744 


\title{
INVESTIGATING THE MANAGEMENT POTENTIAL OF A SEAGRASS MODEL THROUGH SENSITIVITY ANALYSIS AND EXPERIMENTS
}

\author{
Peggy Fong, $, 1,5$ Myrna E. Jacobson, ${ }^{2}$ Mark C. Mescher,${ }^{3}$ Diego Lirman, ${ }^{3}$ And Matthew C. Harwell ${ }^{4}$ \\ ${ }^{1}$ Pacific Estuarine Research Laboratory, Department of Biology, San Diego State University, \\ San Diego, California 92182-0057 USA \\ ${ }^{2}$ Georgia Institute of Technology, Environmental Engineering, MS 0512, Atlanta, Georgia 30332 USA \\ ${ }^{3}$ Rosenstiel School of Marine and Atmospheric Science, University of Miami, 4600 Rickenbacker Causeway, \\ Miami, Florida 33149 USA \\ ${ }^{4}$ School of Marine Science, College of William and Mary, Gloucester Point, Virginia 23062 USA
}

\begin{abstract}
Loss of seagrass-dominated ecosystems worldwide has been attributed to anthropogenic modifications of watersheds; in response, proper management of these systems has become a priority. In this paper, sensitivity analysis and comparison of model predictions to field observations identified conditions under which a subtropical to tropical seagrass ecosystem model would be a useful management tool. Sensitivity analysis indicated that under low-nutrient conditions, physical factors such as temperature, light, and salinity controlled model predictions of seagrass and epiphyte biomass, but that when nutrients were abundant $(5 \mu \mathrm{mol} / \mathrm{L}$ sediment pore water $\mathrm{P} ; 10 \mu \mathrm{mol} / \mathrm{L}$ water column $\mathrm{P}$ ) control shifted to biological interactions. This analysis suggests that important areas for future research include formulations for biomass-dependent productivity (e.g., competition for nutrients or light) and the effects of altered nutrients on epiphyte productivity and shading. Model predictions matched the seasonal abundance of seagrasses measured in three distinct seagrass communities in Biscayne Bay, Florida, suggesting that in its present form the model could be useful to managers to run "what-if" scenarios in order to make long-term decisions about upstream water management practices, including allowable nutrients and freshwater diversion. These management decisions are currently being considered without the benefit of a model.
\end{abstract}

Key words: ecosystem model; Florida; model validation; predictive capability; seagrasses; sensitivity analysis; uncertainty; variability, environmental and seasonal.

\section{INTRODUCTION}

Theoretical models with unknown predictive capabilities can be used to develop more comprehensive, applicable ecological theory and to reveal ecosystem properties (Caswell 1979, Jørgensen 1994). Numerical models that carry uncertainties also fulfill several management functions; they synthesize current knowledge, identify gaps, and aid in directing future research (Ebenhöh 1994, Jørgensen 1994). However, the ultimate objective in many modeling exercises is to increase model applicability to the real world (Bendoricchio et al. 1994, Jeltsch and Wissel 1994, Jørgensen 1994, Kastner-Maresch and Mooney 1994). In an earlier paper, an initial model of a subtropical to tropical seagrass ecosystem was developed, a limited sensitivity analysis conducted, and several model scenarios investigated (Fong and Harwell 1994). At present, the sensitivity of this model to differing parameter values and environmental conditions has not been thoroughly investigated, nor has the range of conditions under

Manuscript received 17 February 1995; revised 10 July 1995; accepted 17 August 1995; final version received 25 September 1995.

${ }^{5}$ Present address: Department of Biology, University of California, Los Angeles, California 90024-1606 USA. which model predictions adequately match ecosystem behavior been established (sensu Mankin et al. 1979). Thus, although model predictions may have been interesting, and the model-building process heuristic, the potential usefulness of this model as a management tool is unknown. On the other hand, management options that will change the quality and quantity of fresh water flowing into coastal seagrass-dominated systems in South Florida are currently being considered without the benefit of a predictive ecosystem model. Once model uncertainties are defined and the model is validated, it will provide an essential tool to explore the effects of these management options on seagrass ecosystems.

Seagrasses are adapted to thrive in low-nutrient, high-light environments (Larkum et al. 1989). In tropical and subtropical regions, the dominant species of seagrass is Thalassia testudinum, although Halodule wrightii and Syringodium filiforme may co-occur or dominate in some areas. The seagrass community also includes different functional forms of algae (sensu Littler and Littler 1980). Macroalgae, such as the rhizophytic algae in the genera Penicillus, Halimeda, and Caulerpa, may be attached to the benthos while both micro- and macroalgae, especially filamentous or sheet-like reds or greens, may grow attached to seagrass blades. Three lines of evidence suggest that phos- 
phorus limits seagrass productivity in tropical and subtropical ecosystems: carbonate geochemical processes may deplete phosphate pools in sediment pore water (Kitano et al. 1978, Short et al. 1985, Morse et al. 1987); field measurements of pore water nutrients have shown that phosphorus is in much lower concentration relative to biological demand than inorganic nitrogen (Short et al. 1985, 1990); and, in a manipulative nutrient enrichment experiment addition of phosphorus alone greatly stimulated primary productivity of Syringodium in the Bahamas (Short et al. 1990). Although subtropical seagrasses, like temperate species (Borum et al. 1989, Pedersen and Borum 1993), may be capable of significant foliar uptake of nutrients, concentrations of $\mathrm{P}$ in the water column in the subtropics are typically extremely low (Nnaji 1987) and unable to support rapid rates of growth frequently measured in the field (for a review of maximum growth rates, see Fong and Harwell 1994).

Several studies correlate rapid growth of the human population in a region with widespread changes in the distribution and abundance of seagrass communities (Cambridge and McComb 1984, Cambridge et al. 1986, Pulich and White 1991). Further evidence suggests that increased anthropogenic nutrient loading may result in a shift in benthic community dominance to epiphytic or benthic algae (Silberstein et al. 1986, Reyes and Merino 1991). There has been a large-scale and progressive die-off of seagrass in Florida Bay (Robblee et al. 1991). Although the cause of this massive die-off is still unknown, there has been tremendous public pressure exerted on the South Florida Water Management District to restore historic flows of water to Florida Bay. Changes in the heavily managed hydrology of South Florida will not only be very expensive, but will have tremendous effects on the environmental conditions (salinity, nutrients, water clarity) of the "downstream" ecosystems. Thus, there is a clear need for a management tool that will enable managers to predict the effects of various freshwater flow scenarios on seagrass ecosystems. At present, approaches for modeling age structure (Cebrián et al. 1994, Duarte et al. 1994) and size structure (P. Ewanchuck and S. L. Williams, unpublished data) of seagrass blades within populations are being developed. However, techniques for modeling changes in subtropical seagrass communities in response to changing environmental conditions are only in the initial phases of development (Fong and Harwell 1994); the present seagrass ecosystem model carries unknown uncertainties.

Two methods of establishing the credibility of a model are to conduct a sensitivity analysis (e.g., KastnerMaresch and Mooney 1994, and many others) and to perform model validation comparisons (Bendoricchio et al. 1994, Jeltsch and Wissel 1994, Kastner-Maresch and Mooney 1994). Sensitivity analysis is the process of making systematic and incremental changes in portions of the model individually, and comparing the re- sults against another simulation in which all model variables are identical except for the single sensitivity test parameter (Tomovic and Vukobratovic 1972, Miller et al. 1973, Miller 1974). This process identifies the model parameters, structures, empirically derived input information, and initial conditions that cause the greatest change in model predictions (Miller 1979). If model predictions are most influenced by sectors of the model that are well known, then the model is considered more reliable. Alternatively, if the most important parameters are those that carry the greatest uncertainty, then future research should be focused on those parameters to improve the model's predictive capabilities. The validation process is analogous to the normal scientific process where hypotheses are subjected to more and more rigorous tests (Popper 1959, 1962). A numerical model is nothing more than a series of hypotheses set into mathematical terms (Caswell 1979). In a validation experiment, the model is altered to simulate various conditions that reflect different natural systems with independent data bases and predictions are compared to field observations. As comparisons identify inconsistencies between simulated and real ecosystem responses, the model structure, formulations, and parameters are altered until confidence is established in the range of conditions under which the model may be considered reliable.

In this paper, we establish the potential usefulness of a seagrass ecosystem model by determining areas of reliability and uncertainty in model structures, parameters, and predictions. To accomplish this objective, we use sensitivity analysis and comparisons of model predictions to field results as validation experiments.

\section{Methods}

\section{Overview of model structure and function}

In our initial model, the seagrass community consisted of five biotic variables, including the three most common species of seagrass, Thalassia testudinum, Halodule wrightii, and Syringodium filiforme, and two functional forms of algae, epiphytes attached to seagrass and rhizophytic macroalgae (Fig. 1a). Five environmental factors were identified as important in controlling both biomass and relative abundance of each of these groups. These included temperature, salinity, light, water column phosphorus (P) concentration, and sediment $\mathrm{P}$ concentration. Model relationships were derived from published results of many laboratory and field studies; model development was thoroughly described in Fong and Harwell (1994), and summarized below.

We built model relationships based on the hypothesis that the productivity (change in biomass) of each species of seagrass is dependent on the total biomass of all three species of seagrass and is also directly controlled by salinity, temperature, light (reaching seagrass blade = light at canopy top - attenuation by epi- 

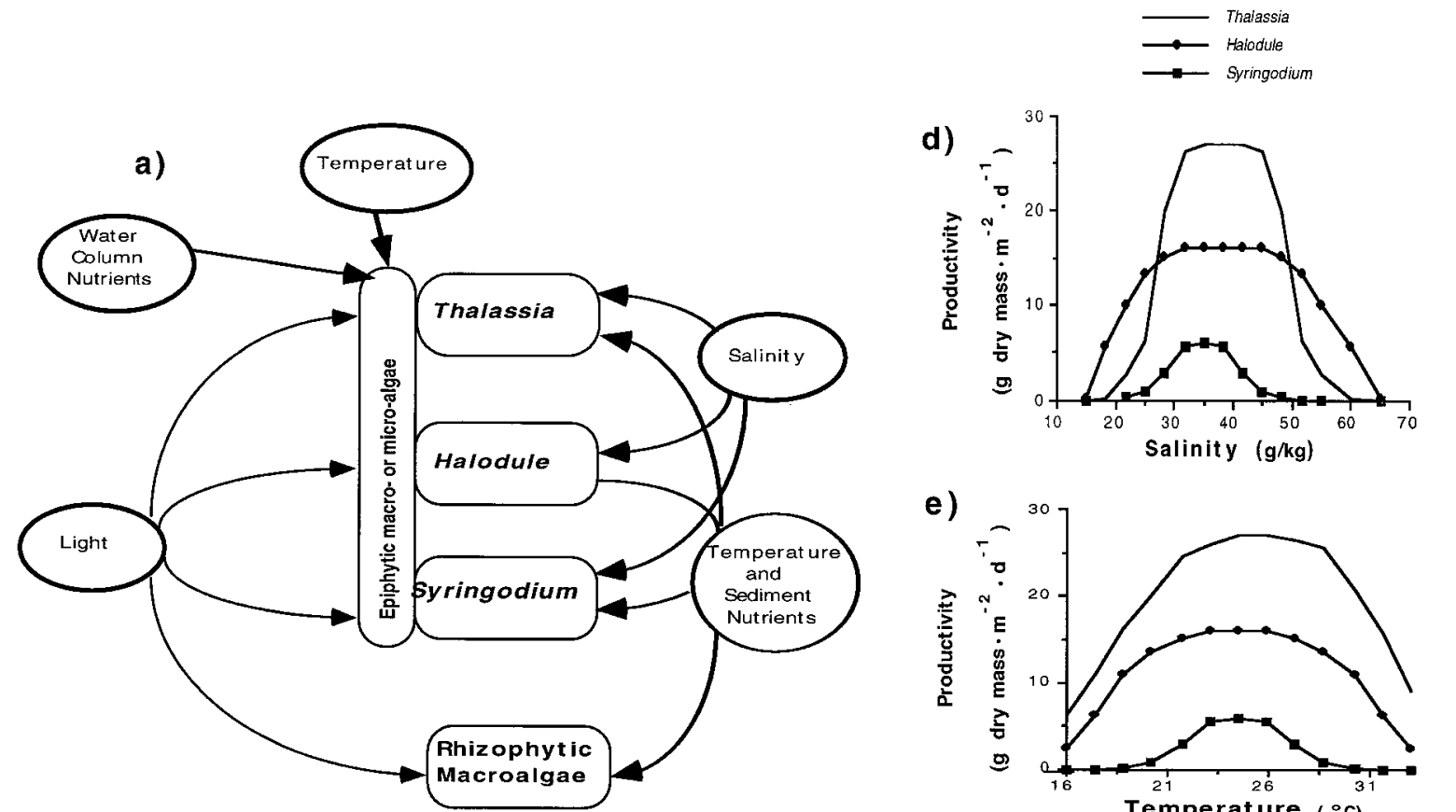
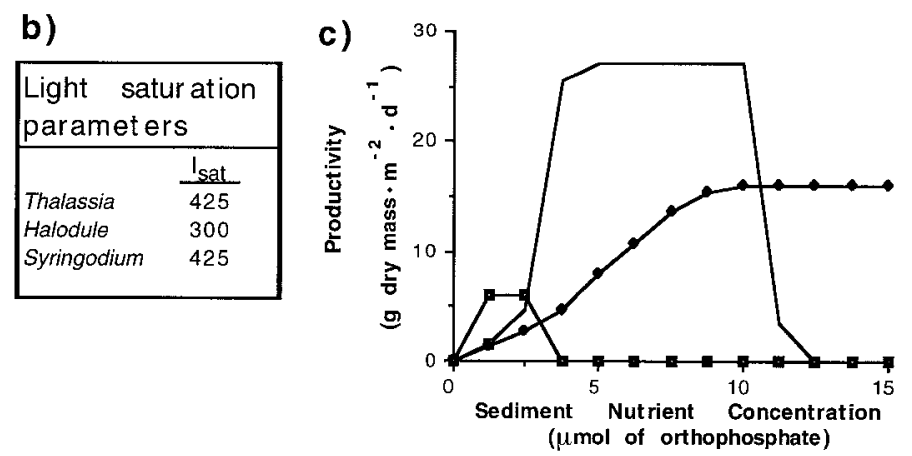
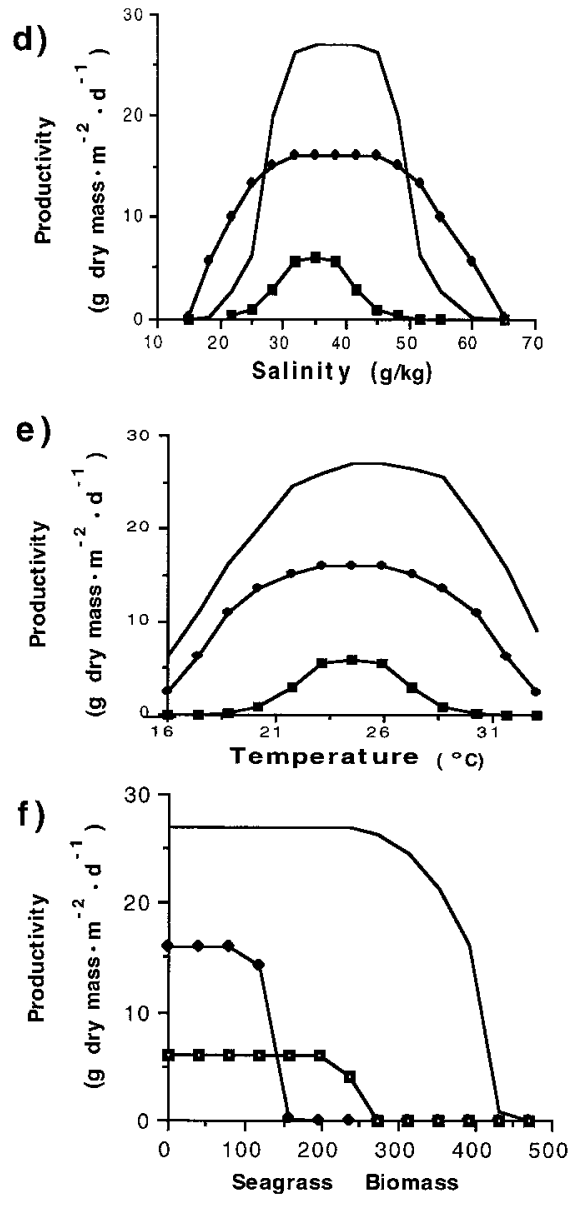

( $g$ dry mass $/ \mathrm{m}^{2}$ )

FIG. 1. (a) Conceptual model of seagrass ecosystem, and graphical representation of model relationships between productivity of seagrass and (b) light, (c) sediment nutrients (pore water + water extractable), (d) water salinity, (e) temperature, and (f) seagrass biomass.

phytes), and sediment $\mathrm{P}$ concentration (Fig. 1b-f). Each species has an optimal productivity rate that occurs within a specific range for each of the environmental factors, and the actual rate is depreciated from the optimal when any of the factors varies outside this range. This depreciation is accomplished by multiplying the maximum productivity by a series of scalars representing each factor that range from 0 to 1 ; this model structure is identical to that used for the ecosystem unit model of the Coastal Ecological Landscape Spatial Simulation Model (Costanza et al. 1990, Costanza and Maxwell 1991). For example, optimal productivity of Thalassia testudinum is $27 \mathrm{~g} \cdot \mathrm{m}^{-2} \cdot \mathrm{d}^{-1}$ (dry mass), and occurs when temperature is $25-27^{\circ} \mathrm{C}$, salinity is $32-45$ $\mathrm{g} / \mathrm{kg}$, total seagrass biomass is $\leq 250 \mathrm{~g} / \mathrm{m}^{2}$ (dry mass), light at the benthos is $\geq 425 \mu \mathrm{mol}$ photons $\cdot \mathrm{m}^{-2} \cdot \mathrm{d}^{-1}$, water column $\mathrm{P}<1.0 \mu \mathrm{mol} / \mathrm{L} \mathrm{PO}_{4}$ so epiphyte biomass is low, and sediment $\mathrm{P}$ is $5-11 \mu \mathrm{mol} / \mathrm{L} \mathrm{PO}_{4}$. Within these optimal ranges, the multiplier that represents the effect of each factor is equal to one and productivity is maximum; outside the range, each multiplier is reduced according to the relationships shown graphically in Fig. 1c-f and using a P/I curve based on the light saturation parameters listed in Fig. 1b. Loss of seagrass biomass is based on average leaf longevity and a constant baseline removal due to physical disturbance associated with currents.

Algal productivity and biomass accumulation are modeled similarly; in the case of epiphytes, maximum growth is $25 \% / \mathrm{d}$, and temperature, irradiance, and water column nutrients are factors that depreciate the maximum productivity outside the optimal range (Fig. 2ac). Loss of epiphytes on seagrass is controlled by both senescence and the turnover time of seagrass blades, as epiphytes are dependent on seagrass as a physical substrate. In the model, we have also incorporated an 

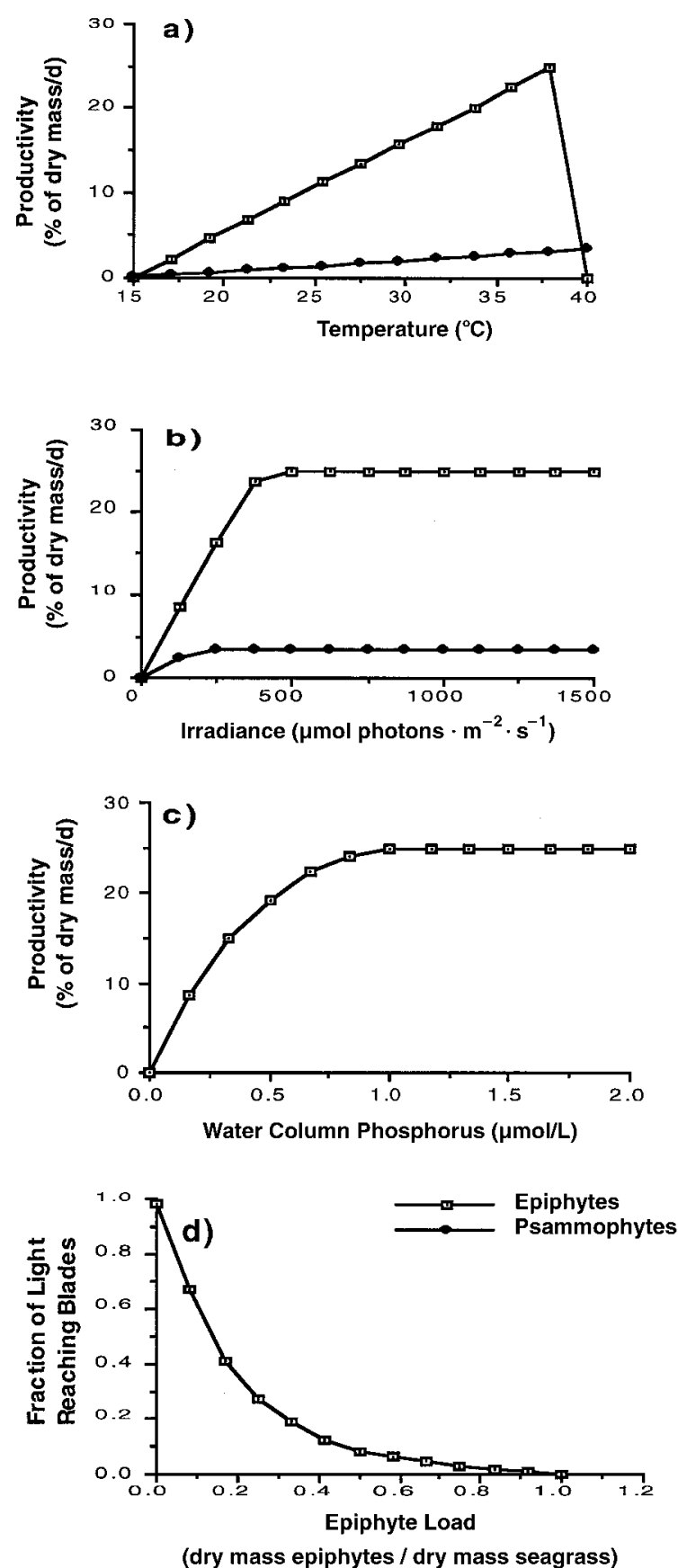

FIG. 2. Model relationships between productivity of epiphytes and (a) water temperature, (b) irradiance, and (c) water column P concentration. Panel d is a graphical representation of the relationship between the epiphyte load on seagrass and the fraction of incident light that the epiphytes block from the seagrass.

important feedback between the abundance of epiphytes and the amount of light reaching seagrass blades. Epiphytes attenuate the amount of light reaching seagrass blades in a biomass-dependent manner (Fig. 2d).
Sensitivity analysis

The sensitivity analysis was conducted in four parts. First, model predictions for each group of primary producer were analyzed for sensitivity to initial conditions, growth rates, and death rates of all groups under low nutrient or "pristine" conditions. Second, sensitivities to interaction terms in the model (epiphyte load, light reaching seagrass through epiphytes, biomass dependence term, and seagrass blade turnover rate) were quantified. Third, the sensitivities of each producer group to the different environmental forcing functions of light, salinity, temperature, water column nutrients, and sediment nutrients were tested. Finally, the entire analysis was repeated for a nutrient-enriched version of the model.

To accomplish the first two objectives, the model was run under low-nutrient baseline conditions and then rerun with each initial condition, physiological rate, and interaction term independently increased and then decreased by $10 \%$ of the baseline value. Baseline conditions were assumed to be in a relatively low-nutrient area (water column $\mathrm{P}=0.15 \mu \mathrm{mol} / \mathrm{L}$, sediment pore water $\mathrm{P}=3 \mu \mathrm{mol} / \mathrm{L}$ ) with moderate temperature and salinity fluctuations modeled with a sinusoidal curve (temperature: minimum $=19^{\circ} \mathrm{C}$ in January, maximum $=33^{\circ} \mathrm{C}$ in June, and average $=26^{\circ} \mathrm{C}$; salinity: minimum $=31 \mathrm{~g} / \mathrm{kg}$ in June, maximum $=39 \mathrm{~g} / \mathrm{kg}$ in January, and average $=35 \mathrm{~g} / \mathrm{kg}$ ), and clear water with abundant light reaching the seagrass blades (minimum $=300 \mu \mathrm{mol}$ photons $\cdot \mathrm{m}^{-2} \cdot \mathrm{s}^{-1}$ in January, maximum $=$ $1100 \mu \mathrm{mol}$ photons $\cdot \mathrm{m}^{-2} \cdot \mathrm{s}^{-1}$ in June, and average $=650$ $\mu \mathrm{mol}$ photons $\cdot \mathrm{m}^{-2} \cdot \mathrm{s}^{-1}$ ). The low-nutrient baseline model was then run for several years, predicting a Thalassia testudinum-dominated mixed seagrass community with low epiphytic algal biomass (Fig. 3). Data from year 2 are presented; in subsequent years Halodule wrightii and epiphytes disappear, while the other groups repeat the seasonal patterns.

To quantify sensitivity to environmental forcing functions two approaches were explored. For the sediment and water column nutrient concentrations the parameters were raised and lowered by $10 \%$. However, seasonal oscillations around an annual mean for light, temperature, and salinity inputs were generated by a sinusoidal function with a period of $1 \mathrm{yr}$. Thus, each curve is described by values for the mean and amplitude. Nine model runs were conducted for each of these variables to account for all possible combinations of alterations in the mean annual value and the amplitude of the seasonal fluctuation (e.g., Table 1 for salinity). As with the parameter alterations the production of each of the five photosynthetic components of the model for each run was reported. For salinity, these altered runs were well within the variability measured by the National Park Service in Biscayne Bay (Nnaji 1987, M. E. Jacobson and P. Fong, unpublished data). Changes in light values are reasonable estimates based 
on field measurements in summer and winter (P. Fong, unpublished data). Ten-percent alterations in mean temperature were chosen to represent warm or cold years while greater seasonal variability (increased amplitude) could represent years when El Niño-Southern Oscillations occur (Nnaji 1987).

To assess how the importance of each parameter changes over an enrichment gradient, the entire sensitivity analysis was repeated under an "enriched" scenario; in this version of the model, baseline water column $\mathrm{P}$ concentrations were increased to $10 \mu \mathrm{mol} / \mathrm{L}$ and sediment concentrations increased to $5 \mu \mathrm{mol} / \mathrm{L}$. This would represent a very enriched water column for a subtropical carbonate-based system. We chose this as our enriched baseline because we wanted to test sensitivity when the $\mathrm{P}$ demand of the primary producers was saturated. This version of the baseline model predicted greater seasonal variability of Thalassia testudinum and a greater winter-spring peak in Halodule wrightii, and increased biomass of epiphytic algae in year 2 (Fig. 4); patterns in subsequent years were the same as shown, with the exception that Syringodium filiforme declined throughout the simulation.

To assess the effects of changes over an entire year, we summed the daily productivity predicted by the model for each producer for year 2 of a simulation. These summed productivities were then used to calculate relative change. Relative sensitivity for each

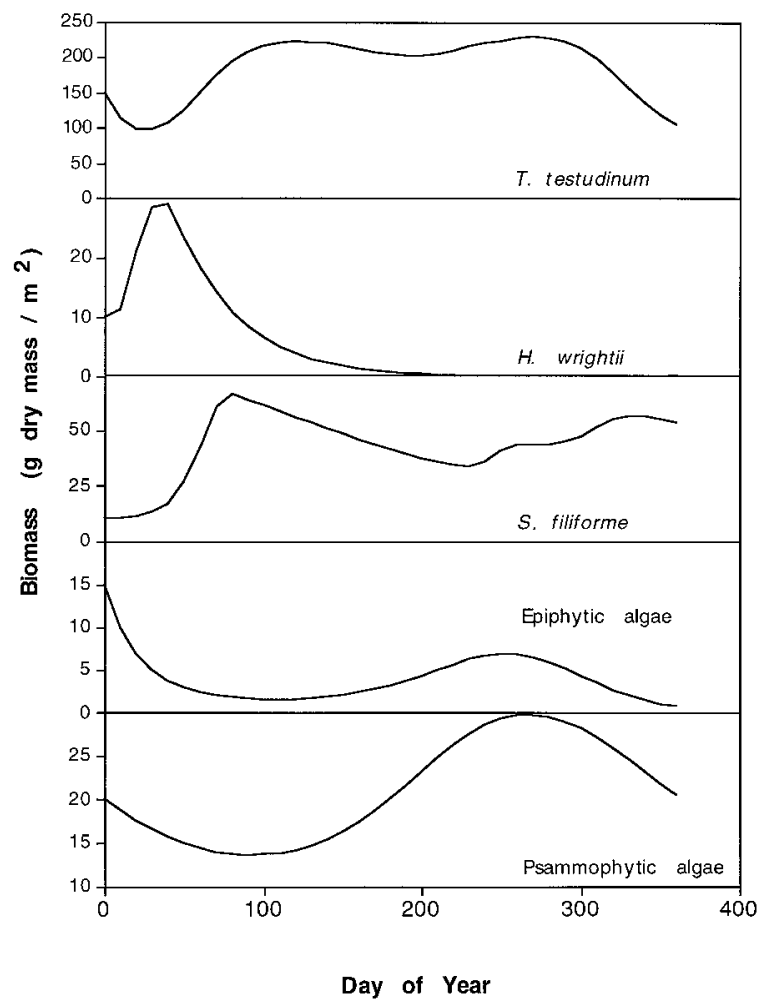

FIG. 3. Model predictions for the low-nutrient baseline used for the sensitivity analysis.
TABLE 1. Example of the experimental design of the sensitivity analysis to quantify the importance of changes in annual mean values and magnitude of seasonal variability for environmental forcing functions in the model. This example shows the altered input values for the nine model runs conducted for salinity as well as the run abbreviation used when presenting the results.

\begin{tabular}{lccc}
\hline \hline & $\begin{array}{c}\text { Abbreviation } \\
(\Delta \text { mean, }\end{array}$ & & \\
Run no. & $\Delta$ amplitude; $\%)$ & Mean & Amplitude \\
\hline 1 (baseline) & 0,0 & 35.0 & 4.0 \\
2 & $0,+10$ & 35.0 & 4.4 \\
3 & $0,-10$ & 35.0 & 3.6 \\
4 & $+10,0$ & 38.5 & 4.0 \\
5 & $+10,+10$ & 38.5 & 4.4 \\
6 & $+10,-10$ & 38.5 & 3.6 \\
7 & $-10,0$ & 31.5 & 4.0 \\
8 & $-10,+10$ & 31.5 & 4.4 \\
9 & $-10,-10$ & 31.5 & 3.6 \\
\hline
\end{tabular}

group of primary producer was calculated as the percent relative change from baseline:

$$
\begin{aligned}
& \text { relative change } \\
& \quad=100 \times\left(\operatorname{rerunP} \mathrm{P}_{(x)}-\text { baseline } \mathrm{P}_{(x)}\right) / \text { baselineP } \\
& \quad(x)
\end{aligned}
$$

where baseline $\mathrm{P}_{(x)}=$ the sum of the daily predicted productivity for primary producer group $x$ in the baseline model, and rerunP $\mathrm{P}_{(x)}=$ the sum of the daily predicted productivity for primary producer group $x$ when a model parameter was changed by $\pm 10 \%$.

Although relative change calculated in this way does not detect seasonal changes, none of the model scenarios shifted the timing of the seasonal patterns; rather the mean and the amplitude of the biomass response was changed among runs. If this model is used in the future to predict management options that include dry season influxes of fresh water, then another method of calculating sensitivity must be developed.

\section{Model validity comparisons: field surveys}

In January and July 1993, a field survey was conducted to characterize the seagrass communities along the western edge of Biscayne Bay, Florida (M. E. Jacobson and P. Fong, unpublished data). The sites used for comparison to model predictions were inshore stations $(\approx 1-1.5 \mathrm{~m}$ in depth) next to Turkey, Fender, and Black Points (Fig. 5). The Turkey Point station was dominated by Thalassia testudinum, Black Point was dominated by Halodule wrightii, and the Fender Point seagrass community was a mix of the two species. We characterized seagrass species abundance (number of blades per square meter and biomass as grams per square meter), blade morphometrics (length, width), biomass of epiphytes (milligrams per square centimeter of blade and grams per square meter), water column nutrient concentration (micromoles per liter) and sediment nutrient concentration (micromoles per liter from pore water + water extracts), temperature, light at the top of the seagrass bed, and salinity. In addition to these 


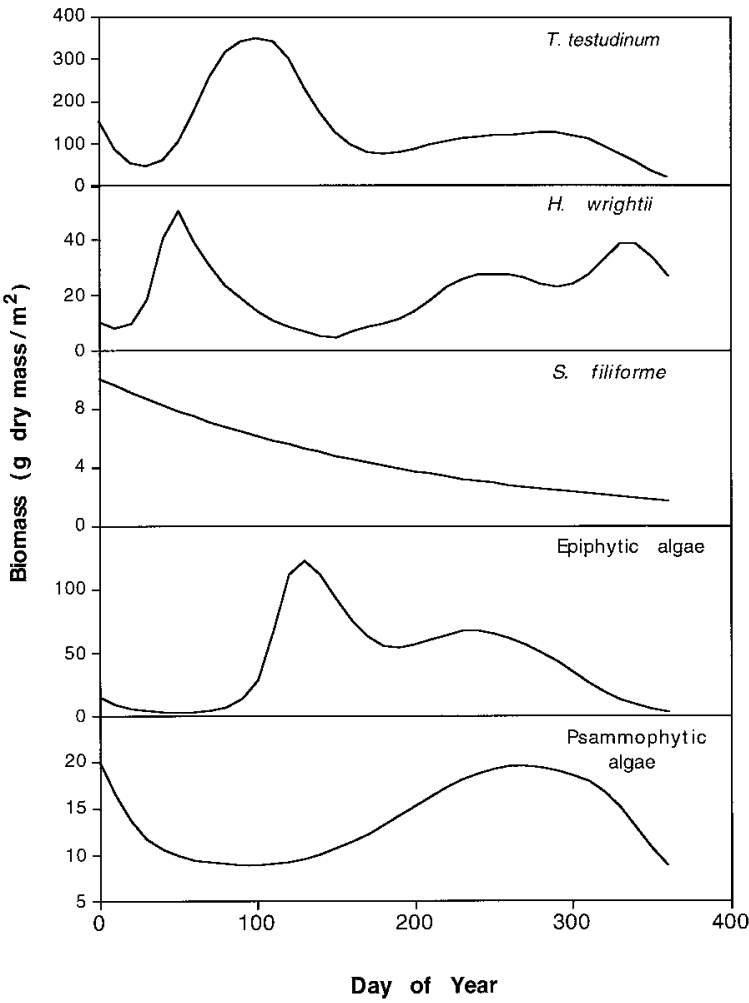

FIG. 4. Model predictions for the nutrient-enriched baseline used for the sensitivity analysis.

data, we used monthly monitoring data collected for 12 yr by Biscayne National Park for a better estimate of seasonal variance in salinity, temperature, and water column nutrient concentrations for each site (Nnaji 1987).

To simulate the seagrass community at Turkey Point, environmental factors in the model were set to the field conditions measured at the Turkey Point station (M. E. Jacobson and P. Fong, unpublished data) or estimated from historical data (Nnaji 1987). Thus, sinusoidal curves for temperature (minimum $=19^{\circ} \mathrm{C}$ in January, maximum $=33^{\circ} \mathrm{C}$ in June, and average $=26^{\circ} \mathrm{C}$ ), salinity (minimum $=31 \mathrm{~g} / \mathrm{kg}$ in June, maximum $=39$ $\mathrm{g} / \mathrm{kg}$ in January, and average $=35 \mathrm{~g} / \mathrm{kg}$ ), and light (minimum $=300 \mu \mathrm{mol}$ photons $\cdot \mathrm{m}^{-2} \cdot \mathrm{s}^{-1}$ in January, maximum $=1100 \mu \mathrm{mol}$ photons $\cdot \mathrm{m}^{-2} \cdot \mathrm{s}^{-1}$ in June, and average $=650 \mu \mathrm{mol}$ photons $\cdot \mathrm{m}^{-2} \cdot \mathrm{s}^{-1}$ ) were used to generate seasonal variation in these environmental conditions. Water column $\mathrm{P}$ concentration was set at 0.15 $\mu \mathrm{mol} / \mathrm{L}$ and sediment $\mathrm{P}$ concentration was set at 3 $\mu \mathrm{mol} / \mathrm{L}$. Nutrient data from the field were highly variable from month to month; thus we used the average value because no clear seasonal pattern was found. We tested the effects of using average values by generating water column $\mathrm{P}$ concentrations for the model by randomly assigning values for each daily iteration from a uniform distribution ranging from the minimum to maximum value. Although model output became more variable for epiphytic algae, predictions fell within the same ranges and followed the same pattern generated when the constant values were used for each site. Similarly, sediment $\mathrm{P}$ concentration in the field was variable in this location; $\mathrm{P}$ concentration measured from replicate cores in January 1993 ranged from 1 to 4 $\mu \mathrm{mol} / \mathrm{L}$. We chose the average value, $3 \mu \mathrm{mol} / \mathrm{L}$, as the concentration of $\mathrm{P}$ in the model run simulating this location.

Model formulations for temperature and light were identical for Fender Point and Turkey Point (estimated from Nnaji 1987). However, the average salinity used for the Fender Point model was lower $(25 \mathrm{~g} / \mathrm{kg})$, and the range broader $(20-30 \mathrm{~g} / \mathrm{kg})$; this range and seasonal pattern reflected the proximity of this station to several freshwater canals. In addition, both water column and sediment nutrients estimated from the field and incorporated into the model were higher, $0.19 \mu \mathrm{mol} / \mathrm{L}$ and $4 \mu \mathrm{mol} / \mathrm{L}$, respectively. Black Point differed from Fender Point only by having a lower, less variable salinity regime (average $=22 \mathrm{~g} / \mathrm{kg}$, range $=20-24 \mathrm{~g} / \mathrm{kg}$ ) because of its location downstream of Black Creek (Nnaji 1987). There were several measurements in Nnaji (1987) that suggested even lower salinity excursions for very short duration, so this formulation may underestimate the importance of low salinity in this area. The model was run for several years under conditions for each of the stations, and model predictions of biomass for year 2 of each simulation were compared for the January and July sampling dates.

\section{Results AND Discussion}

\section{Model sensitivity: initial conditions, growth rates, and death rates}

For the low-nutrient baseline condition, the greatest relative changes were in response to changes in growth rates for all groups of primary producers except the epiphytic algae (Table 2). This high sensitivity to growth reflects the model structure, where nearly all of the forcing functions are dynamically related with the rate of growth while death remains relatively constant. The next greatest changes were in response to death rates. Some believe that rapid mortality of seagrass can occur when changes in environmental conditions are rapid, or multiple stressors co-occur (J. W. Fourqurean and R. T. Zieman, personal communication). However, there are no existing studies that test this hypothesis, so for model development we relied on the existing literature that relates changes in growth to changes in biomass accumulation. Future work should concentrate on developing quantitative relationships between environmental factors and rates of mortality. For all five groups there was little sensitivity to initial conditions after the first year of simulation.

The pattern of sensitivity to initial conditions and rates of growth and death of Thalassia testudinum was unique among the five producer groups (Table 2), re- 


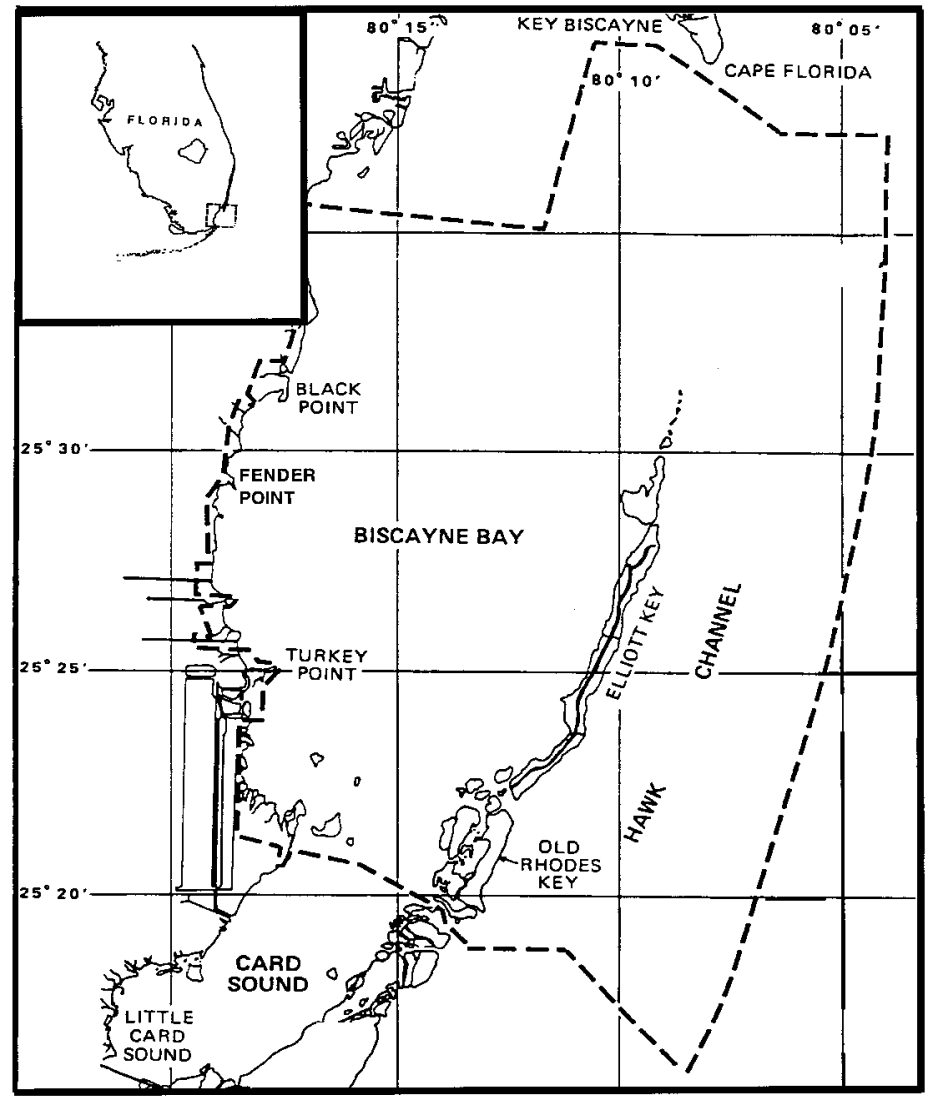

FIG. 5. Biscayne National Park, Florida, site of the field observations and transplant experiments used to compare to model predictions. flecting its position as the superior competitor under low-nutrient baseline conditions (Fong and Harwell 1994). In the baseline run, although biomass varies seasonally, $T$. testudinum is the dominant seagrass throughout the year. Changes in parameters controlling $T$. testudinum caused larger relative changes in predicted biomass for the other species of seagrass than to itself. For example, decreasing the growth rate of $T$. testudinum by $10 \%$ decreased the productivity of $T$. testudinum by $9.57 \%$, but increased the predicted biomass of both Halodule wrightii and Syringodium filiforme by $>20 \%$; the converse was true for increases in growth rate of T. testudinum. For both $S$. filiforme and $H$. wrightii, a $10 \%$ change in initial biomass and rates of growth and death had the greatest effect on within-group productivity, reflecting their subdominant position on the competitive hierarchy under baseline conditions.

Psammophytic macroalgae were insensitive to changes other than to parameters directly controlling their own biomass (Table 2). However, this insensitivity does not necessarily reflect true insensitivity to conditions in the field or lack of interaction with other key community components. Rather, the psammophytic sector of the model was included to acknowledge the importance of this group of algae. As little is known about either within- or among-group dynamics for this type of primary producer, few causal relationships were incorporated into the model. Thus, lack of causal relationships reduced dynamism in this sector of the model. We plan to use this model to test hypotheses concerning the importance of psammophytic macroalgae in a future paper.

Under low-nutrient baseline conditions, epiphytic algal biomass was always extremely low (Fig. 3). Biomass was controlled through a balance between growth and death rates; although epiphytes have potentially very rapid growth, under baseline conditions growth was controlled by severe P limitation. However, small changes in growth and death rates caused very large changes in productivity of epiphytes (Table 2). For example, under low-nutrient baseline conditions, the summed epiphytic algal productivity was $48 \mathrm{~g} \cdot \mathrm{m}^{-2} \cdot \mathrm{yr}^{-1}$ (dry mass); however, increasing the growth rate or decreasing the death rate by $10 \%$ resulted in predicted productivities of $\geq 117 \mathrm{~g} \cdot \mathrm{m}^{-2} \cdot \mathrm{yr}^{-1}$ (dry mass). Despite these large relative changes in epiphytes, relative changes in the other primary producers in response to epiphytes were low. Under low nutrient conditions, even a $140 \%$ change in epiphyte productivity did not have much effect on their seagrass substrate. This suggested that much higher epiphyte productivity was needed to influence the relative abundance of seagrass (e.g., see high-nutrient sensitivity analysis). 
TABLE 2. Sensitivity analysis for parameters associated with the primary producer groups.

\begin{tabular}{|c|c|c|c|c|c|}
\hline \multirow[b]{2}{*}{ Parameter and change } & \multicolumn{5}{|c|}{ Change in gross productivity (\%) } \\
\hline & T. testudinum & H. wrightii & S. filiforme & Epiphytes & $\begin{array}{c}\text { Psammo- } \\
\text { phytes }\end{array}$ \\
\hline \multicolumn{6}{|l|}{ T. testudinum } \\
\hline Initial biomass $+10 \%$ & 0.05 & -11.85 & 0.24 & -0.52 & 0.00 \\
\hline Initial biomass $-10 \%$ & -0.05 & 13.21 & -0.25 & 0.64 & 0.00 \\
\hline Growth rate $+10 \%$ & 9.24 & -18.12 & -24.58 & 0.83 & 0.00 \\
\hline Growth rate $-10 \%$ & -9.57 & 20.13 & 26.93 & -0.83 & 0.00 \\
\hline Death rate $+10 \%$ & 0.45 & 22.76 & 23.82 & -1.14 & 0.00 \\
\hline Death rate $-10 \%$ & -0.82 & -24.47 & -26.07 & 1.49 & 0.00 \\
\hline \multicolumn{6}{|l|}{ H. wrightii } \\
\hline Initial biomass $+10 \%$ & 0.00 & -1.59 & 0.00 & 0.02 & 0.00 \\
\hline Initial biomass $-10 \%$ & 0.00 & 1.61 & 0.00 & -0.04 & 0.00 \\
\hline Growth rate $+10 \%$ & 0.01 & 4.21 & -0.13 & 0.06 & 0.00 \\
\hline Growth rate $-10 \%$ & -0.01 & -4.69 & 0.15 & -0.08 & 0.00 \\
\hline Death rate $+10 \%$ & 0.00 & 2.63 & 0.48 & -0.04 & 0.00 \\
\hline Death rate $-10 \%$ & 0.00 & -2.63 & -0.55 & 0.04 & 0.00 \\
\hline \multicolumn{6}{|l|}{ S. filiforme } \\
\hline Initial biomass $+10 \%$ & 0.00 & -2.65 & -0.36 & 0.04 & 0.00 \\
\hline Initial biomass $-10 \%$ & 0.00 & 2.68 & 0.37 & -0.06 & 0.00 \\
\hline Growth rate $+10 \%$ & -0.09 & -1.51 & 3.75 & 0.08 & 0.00 \\
\hline Growth rate $-10 \%$ & 0.10 & 1.61 & -4.06 & -0.08 & 0.00 \\
\hline Death rate $+10 \%$ & 0.08 & 0.52 & 3.23 & -0.02 & 0.00 \\
\hline Death rate $-10 \%$ & -0.09 & -0.52 & -3.43 & 0.02 & 0.00 \\
\hline \multicolumn{6}{|l|}{ Psammophytic algae } \\
\hline Initial biomass $+10 \%$ & 0.00 & 0.00 & 0.00 & 0.00 & 10.00 \\
\hline Initial biomass $-10 \%$ & 0.00 & 0.00 & 0.00 & 0.00 & -10.00 \\
\hline Growth rate $+10 \%$ & 0.00 & 0.00 & 0.00 & 0.00 & 67.84 \\
\hline Growth rate $-10 \%$ & 0.00 & 0.00 & 0.00 & 0.00 & -38.65 \\
\hline Death rate $+10 \%$ & 0.00 & 0.00 & 0.00 & 0.00 & -31.59 \\
\hline Death rate $-10 \%$ & 0.00 & 0.00 & 0.00 & 0.00 & 50.79 \\
\hline \multicolumn{6}{|l|}{ Epiphytic algae } \\
\hline Initial biomass $+10 \%$ & -0.18 & 3.94 & 0.07 & 8.60 & 0.00 \\
\hline Initial biomass $-10 \%$ & 0.18 & -4.04 & -0.06 & -8.83 & 0.00 \\
\hline Growth rate $+10 \%$ & -1.44 & 0.67 & 6.99 & 143.63 & 0.00 \\
\hline Growth rate $-10 \%$ & 0.30 & -0.64 & -0.92 & -54.53 & 0.00 \\
\hline Death rate $+10 \%$ & 0.42 & -2.93 & -0.98 & -55.48 & 0.00 \\
\hline Death rate $-10 \%$ & -1.98 & 3.40 & 8.71 & 146.72 & 0.00 \\
\hline \multicolumn{6}{|l|}{ Interaction parameters } \\
\hline Light at blade $+10 \%$ & 1.58 & -15.27 & -2.04 & 6.42 & 0.00 \\
\hline Light at blade $-10 \%$ & -2.06 & 16.96 & 3.86 & -7.81 & 0.00 \\
\hline Grass biomass $+10 \%$ & -0.75 & -38.55 & -28.30 & 0.50 & 0.00 \\
\hline Grass biomass $-10 \%$ & 0.47 & 48.09 & 36.93 & -0.50 & 0.00 \\
\hline Turnover rate $+10 \%$ & -0.09 & 0.27 & 0.31 & 11.68 & 0.00 \\
\hline Turnover rate $-10 \%$ & 0.08 & -0.25 & -0.24 & -10.32 & 0.00 \\
\hline
\end{tabular}

Of the parameters controlling interactions among the groups of primary producers, the hierarchy of sensitivity was Total Biomass $>$ Light at Blade $>$ Seagrass Turnover rate (Table 2). Biomass-dependent growth was a very important parameter controlling relative abundance of seagrasses, with sensitivity decreasing in order of Halodule wrightii $>$ Syringodium filiforme $>$ Thalassia testudinum. The next most important interaction factor was the relationship between epiphytes and the amount of light reaching the blades of seagrass, a function of the seasonal light intensity and epiphyte biomass (shading). In the low-nutrient baseline, increasing the amount of light reaching the seagrass blades increased the relative productivity of $T$. testudinum marginally, but decreased the relative productivity of the other two species of seagrass to a greater degree. This decrease in the other two species of seagrass in response to increased light was a result of the biomass-dependent growth functions; increased biomass of $T$. testudinum reduced the growth of the other seagrass species. Reduced amount of light reaching seagrass blades favored $H$. wrightii and $S$. filiforme, as they had the lowest light requirement. Last, changing the turnover rate, or lengthening the amount of time that seagrass blades remained alive, produced the greatest relative change for epiphytes. Decreasing turnover time reduced epiphyte mortality due to substrate loss.

\section{Model sensitivity: environmental forcing functions}

Changes in temperature had the greatest effect on model predictions (Fig. 6a); this was a reasonable result for a subtropical seagrass community adapted to rel- 
a)

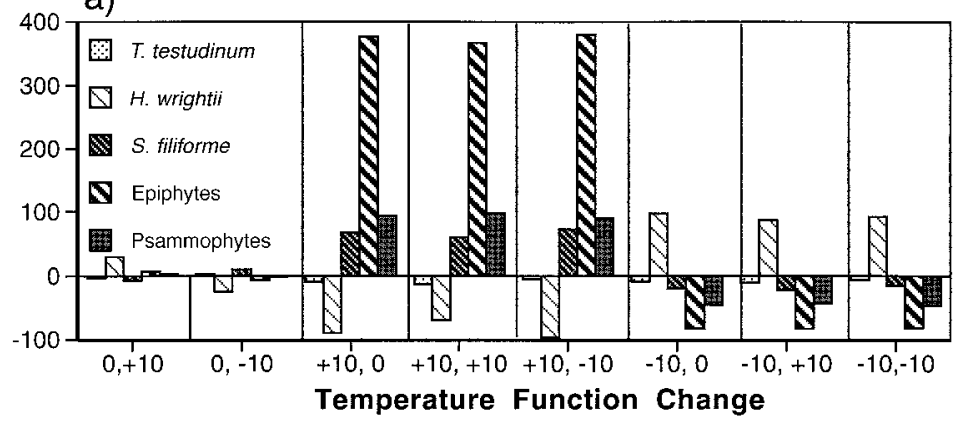

b)

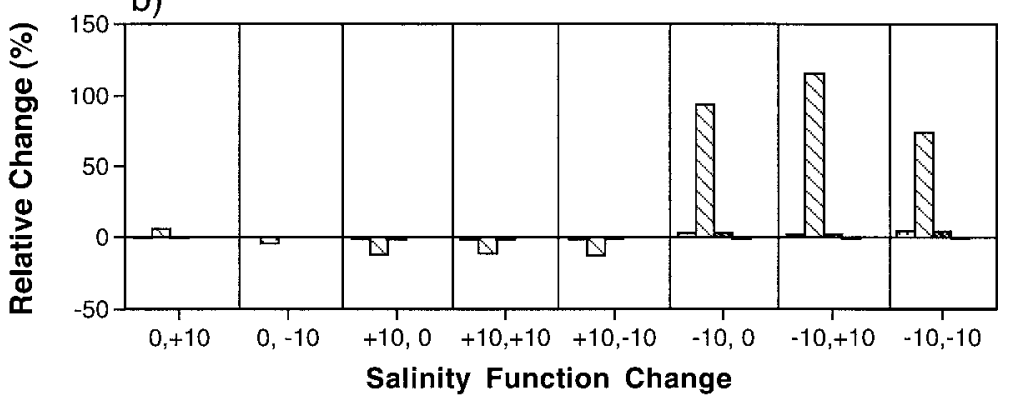

c)

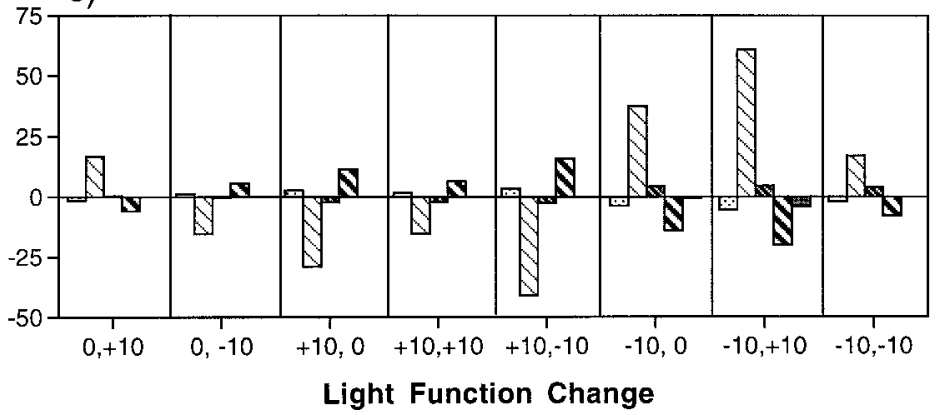

FIG. 6. Sensitivity of the low-nutrient baseline model to changes in the sine curve that generated seasonal variability in (a) temperature, (b) salinity, and (c) light. The model was run altering both the mean and amplitude of the function independently. Thus, in the first run $(0,+10)$, the mean was unchanged, but the amplitude was increased by $10 \%$. Similarly, in the final model run $(-10,-10)$, both the mean and amplitude were decreased by $10 \%$.

atively high temperatures with little seasonal fluctuation (Larkum et al. 1989). Changes in temperature had the greatest effect on epiphytic algae. This was due to the linear increase in productivity with temperature modeled for epiphytes (Fig. 2a); unfortunately, this relationship is one of the least certain of the model formulations (Fong and Harwell 1994), and needs more research. Seagrasses were less sensitive to change in temperature, with a hierarchy of Halodule wrightii $>$ Syringodium filiforme $>$ Thalassia testudinum. None of the groups of primary producers were affected greatly by changes in the amplitude of the sine curve (analogous to increased seasonal variability); rather, the largest relative changes occurred when mean annual temperature was increased by $10 \%$. Predicted productivity for both forms of algae as well as $S$. filiforme were positively related to changes in temperature while
H. wrightii was negatively related. This was because, in model formulation, optimum growth conditions for $S$. filiforme and algae were higher than those in the baseline simulation. Conversely, for $H$. wrightii, optimum temperatures were lower than baseline conditions. T. testudinum had maximum growth rate at the baseline temperature conditions, so that both increased and decreased temperatures negatively affected predicted productivity. Optimal temperatures for each species of seagrass were determined from published field studies correlating temperature and seagrass productivity (summarized in Fong and Harwell 1994).

Predictions of productivity for Halodule wrightii were sensitive to changes in water salinity (Fig. 6b); lowered salinity enhanced predictions over baseline by over $100 \%$. However, none of the other primary producers were very sensitive to changes in salinity. In 


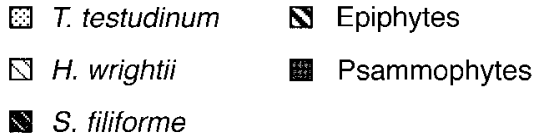

a)

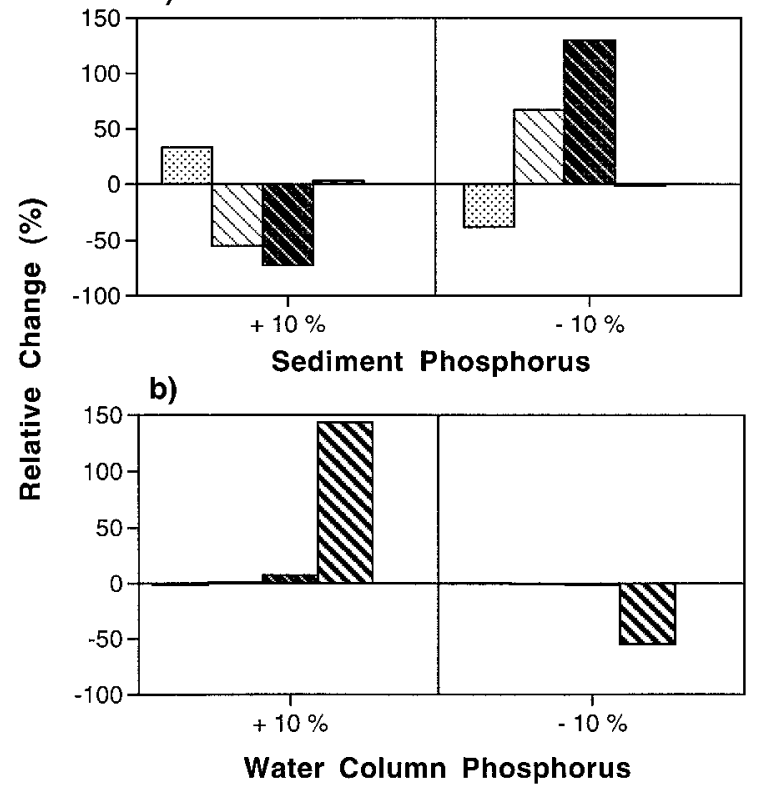

FIG. 7. Sensitivity of the low-nutrient model to changes in (a) sediment and (b) water column $\mathrm{P}$ concentration.

the model, $H$. wrightii and Thalassia testudinum had equal tolerances to high salinity, but $H$. wrightii could grow at its optimum rate at salinities as low as $30 \mathrm{~g} / \mathrm{kg}$, lower than the other seagrasses. As $H$. wrightii is not a competitive dominant, increases in $H$. wrightii did not directly affect other seagrasses. As in the sensitivity to light, predictions were affected more by changes in the mean than the amplitude of the salinity function.

Model predictions were the least sensitive to changes in light than any other of the environmental forcing functions (Fig. 6c). Changes in light affected Halodule wrightii to the greatest degree, followed by epiphytic algae; the magnitudes of change of these two groups of primary producers were proportional to each other, but in opposite directions. Changes in the predicted biomass of Syringodium filiforme were in the same direction as $H$. wrightii, but of lesser magnitude while small changes in Thalassia testudinum were in the same direction as those for epiphytes. In general, H. wrightii biomass increased when light levels were lower (decrease in mean) or more variable (increase in amplitude), reflecting the lower light saturation level of this species of seagrass. T. testudinum had a higher light requirement, and reduced growth of this dominant species allowed $H$. wrightii and $S$. filiforme to increase in biomass. Small changes in T. testudinum were responsible for the larger changes in epiphyte biomass as epiphytes had relatively low light requirements, but were dependent on T. testudinum for substrate.
All three species of seagrass were sensitive to changes in the sediment $\mathrm{P}$ concentration while only epiphytes and, to a lesser extent, psammophytes were sensitive to changes in water-column $\mathrm{P}$ concentration (Fig. 7a). Increasing the sediment $\mathrm{P}$ increased the productivity of Thalassia testudinum, the dominant species, and the subsequent change in T. testudinum biomass decreased the productivity of the other seagrasses. Epiphyte productivity was slightly increased as there was more of the T. testudinum substrate available. Decreasing the sediment $\mathrm{P}$ had the inverse effect on each of the groups of primary producers.

Increasing water column $\mathrm{P}$ increased the abundance of epiphytes (Fig. 7b). This increase in epiphytes decreased the amount of Thalassia testudinum only slightly, but that slight increase released Syringodium filiforme from competition and productivity of that species of seagrass was elevated. Decreased epiphytes occurred when water column $\mathrm{P}$ was lowered, but had no secondary effects on $T$. testudinum biomass as epiphytes are not controlling T. testudinum under this low nutrient scenario.

\section{Model sensitivity: low-nutrient vs. enriched ecosystems}

One important difference between the low-nutrient and enriched model was the predictions of biomass accumulation for Syringodium filiforme. In the enriched model run, biomass of $S$. filiforme decreased throughout the simulation (Fig. 4 shows year 2), disappearing during year 3. In the model (Fig. 1), growth of S. filiforme was reduced at the higher sediment nutrient concentrations simulated in the enriched model (sediment $\mathrm{P}$ in enriched $=5 \mu \mathrm{mol} / \mathrm{L}$ ), this was based on the hypothesis that $S$. filiforme is an inferior competitor for space under enriched conditions (Fong and Harwell 1994). In the enriched baseline sensitivity analysis, decreased productivity of $S$. filiforme resulted in its insensitivity to changes in any model parameter (Table 3). Similarly, changes in the initial biomass, growth, and death rate of $S$. filiforme did not result in large changes in other predictions. This result supports correlative field observations that Syringodium generally occurs in oceanic environments, with lower sediment nutrients than bays or estuaries associated with continents (Short et al. 1985, 1990), but is not important in enriched seagrass systems.

In general, the enriched model predictions for all five groups of producers were less than or equally sensitive to initial conditions as the low-nutrient model (for key differences see Table 4). There were two large changes in sensitivity to initial conditions between scenarios. First, sensitivity of epiphytic algae to its own initial biomass decreased by more than an order of magnitude; this reflects a release from nutrient limitation and a larger biomass accumulation in this scenario, damping the effect of initial biomass. Second, sensitivity of Halodule wrightii to the initial biomass of Thalassia tes- 
TABLE 3. Sensitivity analysis for parameters associated with the primary producer groups for the enriched baseline analysis.

\begin{tabular}{|c|c|c|c|c|c|}
\hline \multirow[b]{2}{*}{ Parameter and change } & \multicolumn{5}{|c|}{ Change in gross productivity (\%) } \\
\hline & T. testudinum & H. wrightii & S. filiforme & Epiphytes & $\begin{array}{c}\text { Psammo- } \\
\text { phytes }\end{array}$ \\
\hline \multicolumn{6}{|l|}{ T. testudinum } \\
\hline Initial biomass $+10 \%$ & 0.11 & -0.56 & 0.00 & 0.04 & 0.00 \\
\hline Initial biomass $-10 \%$ & -0.13 & 2.05 & 0.00 & -0.03 & 0.00 \\
\hline Growth rate $+10 \%$ & 8.51 & -32.97 & 0.00 & 5.13 & 0.00 \\
\hline Growth rate $-10 \%$ & -8.75 & 40.78 & 0.00 & -4.89 & 0.00 \\
\hline Death rate $+10 \%$ & 1.06 & 39.37 & 0.00 & -5.12 & 0.00 \\
\hline Death rate $-10 \%$ & -1.25 & -38.68 & 0.00 & 6.69 & 0.00 \\
\hline \multicolumn{6}{|l|}{ H. wrightii } \\
\hline Initial biomass $+10 \%$ & 0.00 & -0.06 & 0.00 & 0.01 & 0.00 \\
\hline Initial biomass $-10 \%$ & 0.00 & 0.07 & 0.00 & -0.01 & 0.00 \\
\hline Growth rate $+10 \%$ & 0.01 & 4.90 & 0.00 & 0.53 & 0.00 \\
\hline Growth rate $-10 \%$ & -0.01 & -5.23 & 0.00 & -0.56 & 0.00 \\
\hline Death rate $+10 \%$ & 0.02 & 4.74 & 0.00 & -0.36 & 0.00 \\
\hline Death rate $-10 \%$ & -0.02 & -4.98 & 0.00 & 0.41 & 0.00 \\
\hline \multicolumn{6}{|l|}{ S. filiforme } \\
\hline Initial biomass $+10 \%$ & -0.02 & -0.79 & 0.00 & 0.16 & 0.00 \\
\hline Initial biomass $-10 \%$ & 0.02 & 0.80 & 0.00 & -0.16 & 0.00 \\
\hline Growth rate $+10 \%$ & 0.00 & 0.00 & 0.00 & 0.00 & 0.00 \\
\hline Growth rate $-10 \%$ & 0.00 & 0.00 & 0.00 & 0.00 & 0.00 \\
\hline Death rate $+10 \%$ & 0.01 & 0.91 & 0.00 & -0.14 & 0.00 \\
\hline Death rate $-10 \%$ & -0.01 & -1.04 & 0.00 & 0.15 & 0.00 \\
\hline \multicolumn{6}{|l|}{ Psammophytic algae } \\
\hline Initial biomass $+10 \%$ & 0.00 & 0.00 & 0.00 & 0.00 & 10.00 \\
\hline Initial biomass $-10 \%$ & 0.00 & 0.00 & 0.00 & 0.00 & -10.00 \\
\hline Growth rate $+10 \%$ & 0.00 & 0.00 & 0.00 & 0.00 & 67.84 \\
\hline Growth rate $-10 \%$ & 0.00 & 0.00 & 0.00 & 0.00 & -38.65 \\
\hline Death rate $+10 \%$ & 0.00 & 0.00 & 0.00 & 0.00 & -31.59 \\
\hline Death rate $-10 \%$ & 0.00 & 0.00 & 0.00 & 0.00 & 50.79 \\
\hline \multicolumn{6}{|l|}{ Epiphytic algae } \\
\hline Initial biomass $+10 \%$ & -0.59 & 0.42 & 0.00 & 0.22 & 0.00 \\
\hline Initial biomass $-10 \%$ & 0.64 & -0.46 & 0.00 & -0.28 & 0.00 \\
\hline Growth rate $+10 \%$ & -6.82 & 29.14 & 0.00 & 2.09 & 0.00 \\
\hline Growth rate $-10 \%$ & 8.26 & -30.74 & 0.00 & -2.51 & 0.00 \\
\hline Death rate $+10 \%$ & 7.74 & -32.73 & 0.00 & 7.34 & 0.00 \\
\hline Death rate $-10 \%$ & -7.52 & 37.07 & 0.00 & -7.70 & 0.00 \\
\hline \multicolumn{6}{|l|}{ Interaction parameters } \\
\hline Light at blade $+10 \%$ & 1.31 & -4.75 & 0.00 & 6.97 & 0.00 \\
\hline Light at blade $-10 \%$ & -1.48 & 6.47 & 0.00 & -7.26 & 0.00 \\
\hline Grass biomass $+10 \%$ & -1.29 & -36.66 & 0.00 & 5.78 & 0.00 \\
\hline Grass biomass $-10 \%$ & 1.27 & 57.46 & 0.00 & -5.70 & 0.00 \\
\hline Turnover time $+10 \%$ & -0.91 & 4.80 & 0.00 & -0.74 & 0.00 \\
\hline Turnover time $-10 \%$ & 0.91 & -4.63 & 0.00 & 0.74 & 0.00 \\
\hline
\end{tabular}

tudinum decreased 20 -fold in the enriched model, suggesting that with enrichment $T$. testudinum exerts less control over the productivity of $H$. wrightii.

Productivity of both Halodule wrightii and epiphytic algae had greater sensitivity to changes in growth rate of Thalassia testudinum in the enriched than the lownutrient analysis (Table 4). Increased $H$. wrightii sensitivity in the enriched baseline model reflected its higher productivity rate in the enriched model, and the greater relative importance of $H$. wrightii in enriched environments (Powell et al. 1989). This result supports the hypothesis that $T$. testudinum may not suppress $H$. wrightii productivity as strongly under enriched conditions, as $H$. wrightii was able to proliferate in these model conditions. Increased epiphytic sensitivity to the growth rate of $T$. testudinum suggests that in this scenario, $T$. testudinum as substrate for epiphytes was more limiting than water column P. This interdependence was supported by the increased sensitivity of both species of seagrass to changes in the growth rate of epiphytic algae.

Sensitivities of model predictions to death rates were greater in the enriched baseline (Table 3). The greatest change in sensitivity was due to changes in the death rate of epiphytes (Table 4), reflecting the greater importance of epiphytes in model dynamics under enriched conditions. A $10 \%$ increase or decrease in the death rate of epiphytes produced a 7-10 fold increase in the relative change of both Thalassia testudinum and Halodule wrightii. However, epiphytes were less sen- 
TABLE 4. Summary of key differences in results of sensitivity analyses of the low-nutrient and enriched models.

\begin{tabular}{|c|c|c|c|c|}
\hline \multirow[b]{2}{*}{ Parameter } & \multirow[b]{2}{*}{ Change } & \multirow[b]{2}{*}{ Key response variable } & \multicolumn{2}{|c|}{ Change in gross productivity $(\%)$} \\
\hline & & & Low nutrient & Enriched \\
\hline \multicolumn{5}{|l|}{ Initial conditions } \\
\hline Epiphytes & $\begin{array}{l}+10 \% \\
-10 \%\end{array}$ & Epiphytes & $\begin{array}{r}8.60 \\
-8.83\end{array}$ & $\begin{array}{r}0.22 \\
-0.28\end{array}$ \\
\hline T. testudinum & $\begin{array}{l}+10 \% \\
-10 \%\end{array}$ & H. wrightii & $\begin{array}{r}-11.85 \\
13.21\end{array}$ & $\begin{array}{r}-0.56 \\
2.05\end{array}$ \\
\hline \multicolumn{5}{|l|}{ Growth rates } \\
\hline T. testudinum & $\begin{array}{l}+10 \% \\
-10 \%\end{array}$ & H. wrightii & $\begin{array}{r}-18.12 \\
20.13\end{array}$ & $\begin{array}{r}-32.97 \\
40.78\end{array}$ \\
\hline T. testudinum & $\begin{array}{l}+10 \% \\
-10 \%\end{array}$ & Epiphytes & $\begin{array}{r}0.83 \\
-0.83\end{array}$ & $\begin{array}{r}5.13 \\
-4.89\end{array}$ \\
\hline \multicolumn{5}{|l|}{ Death rates } \\
\hline Epiphytes & $\begin{array}{l}+10 \% \\
-10 \%\end{array}$ & T. testudinum & $\begin{array}{r}0.42 \\
-1.98\end{array}$ & $\begin{array}{r}7.74 \\
-7.52\end{array}$ \\
\hline Epiphytes & $\begin{array}{l}+10 \% \\
-10 \%\end{array}$ & H. wrightii & $\begin{array}{r}-2.93 \\
3.40\end{array}$ & $\begin{array}{r}-32.73 \\
37.07\end{array}$ \\
\hline \multicolumn{5}{|c|}{ Interaction parameters } \\
\hline Grass biomass & $\begin{array}{l}+10 \% \\
-10 \%\end{array}$ & Epiphytes & $\begin{array}{r}0.50 \\
-0.50\end{array}$ & $\begin{array}{r}5.78 \\
-5.70\end{array}$ \\
\hline Turnover time & $\begin{array}{l}+10 \% \\
-10 \%\end{array}$ & Epiphytes & $\begin{array}{r}11.68 \\
-10.32\end{array}$ & $\begin{array}{r}-0.74 \\
0.74\end{array}$ \\
\hline
\end{tabular}

sitive to their own death rate (Table 3). Similarly, the increase in $H$. wrightii's sensitivity to changes in both $T$. testudinum and $H$. wrightii death rates under enriched conditions supports the hypothesis that $H$. wrightii has a larger role in the dynamics controlling community structure under enriched conditions. Finally, in the enriched model, epiphytes showed greater sensitivity to the death rates of both $T$. testudinum and $H$. wrightii, demonstrating the tighter coupling between the epiphytes and their seagrass substrate under enriched conditions.

The interaction parameters of light reaching seagrass blades and seagrass blade turnover time produced different model sensitivities under enriched conditions (Table 3). In the enriched model, epiphytes showed increased sensitivity to seagrass biomass, but decreased sensitivity to seagrass turnover time (Table 4). Under low nutrient conditions, epiphytes are controlled by the senescence rate of their seagrass substrate; however, under the enriched conditions it appears that epiphytes are controlling the abundance of seagrass, releasing them from control by senescence.

Model predictions were less sensitive to changes in temperature under enriched conditions (compare Figs. $6 a$ and $8 a$ ). This was largely due to the lack of sensitivity of epiphytes and Syringodium filiforme. In addition, Halodule wrightii was less sensitive to changes in temperature, especially increases in average temperature. Similarly, $H$. wrightii is about half as sensitive to changes in salinity under enriched conditions; this may be in response to the increased sensitivity of Thalassia testudinum (compare Figs. 6b and 8b). Overall, sensitivity of the primary producer groups to light also decreased, although the ranks of importance were un- changed (compare Figs. 6c and 8c). The net decrease in the sensitivity of model predictions to changes in physical factors suggests that in the enriched ecosystem, control of community structure is less dependent on these physical parameters and more dependent on biological interactions.

Finally, there was a large decrease in the sensitivity of each of the producer groups to both water column and sediment nutrients. Under enriched conditions, the model was completely insensitive to $10 \%$ changes in water column P. Sensitivity to sediment $\mathrm{P}$ was greatly reduced (compare Figs. 7a and 9). In the low-nutrient baseline model, both water column and sediment $\mathrm{P}$ were in limiting concentrations while in the enriched conditions, nutrients in both pools were in saturating concentrations, even with a $10 \%$ reduction.

\section{Model validity: comparison to field surveys}

When the model was run under the conditions found at Turkey Point, the model predicted that Halodule wrightii would never dominate the seagrass community (Fig. 10a). Biomass of $H$. wrightii ranged from 0 to 5 $\mathrm{g} / \mathrm{m}^{2}$, with peak biomass early in the year. In the field, biomass of $H$. wrightii at Turkey Point never exceeded $2 \mathrm{~g} / \mathrm{m}^{2}$, supporting the model prediction of low biomass at this site. The model predicted that Thalassia testudinum would dominate at Turkey Point, with the lowest biomass in winter and the highest in summer (Fig. 10b) and that Syringodium filiforme would be absent. The model suggests that dominance by $T$. testudinum was related to the lack of extreme conditions at this site; throughout the entire year, salinity, temperature, and sediment nutrients were in the optimal range for $T$. testudinum; in all but winter, light exceeded saturation 
a)

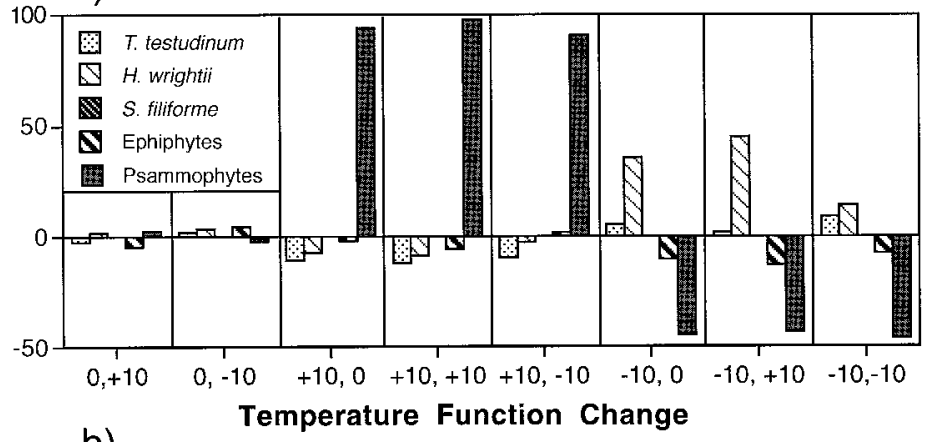

b)

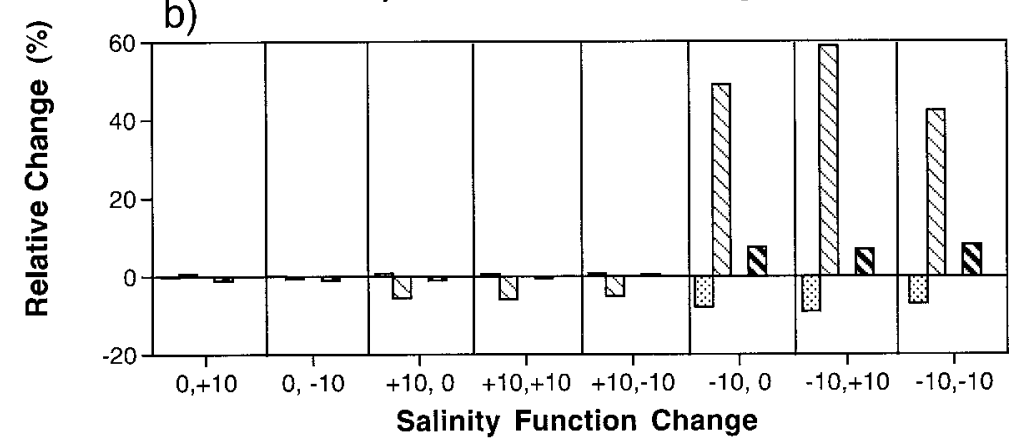

c)

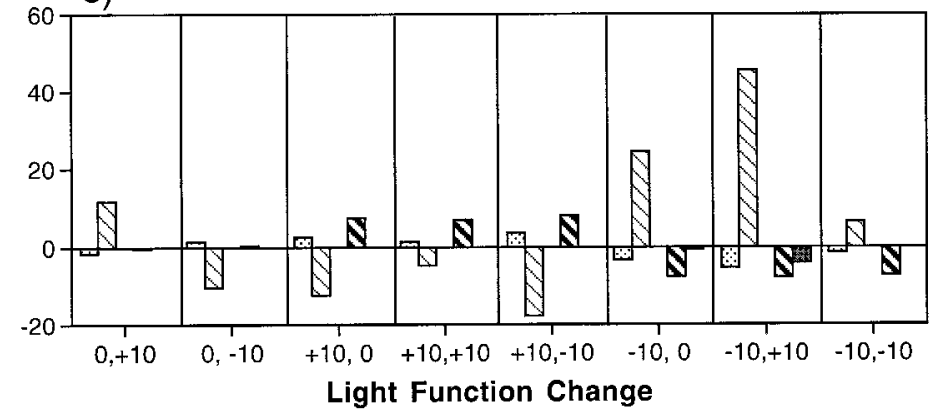

FIG. 8. Sensitivity of the nutrient-enriched baseline model to changes in the sine curve that generated seasonal variability in (a) temperature, (b) salinity, and (c) light. The $x$ axes are labeled for various runs as described for Fig. 6.

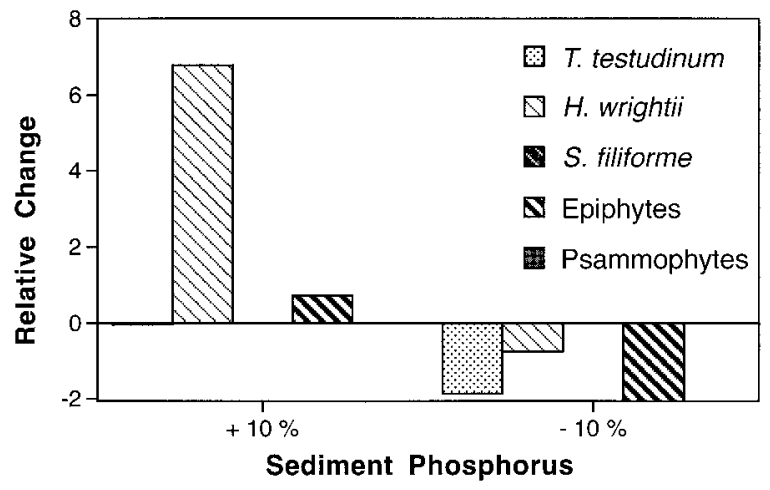

FIG. 9. Sensitivity of the nutrient-enriched baseline model to changes in sediment $\mathrm{P}$ concentration. This version of the model was insensitive to changes in water-column P concentration. irradiance and temperature exceeded the minimum value for optimal growth. Model predictions fell within the standard error of the field measurements both in winter and summer, suggesting that the model is predicting seasonal variability relatively accurately. The model predicted that there would be a slight midsummer drop in biomass related to elevated temperature. Field data of biomass and the physical-chemical forcing functions collected at a finer temporal resolution will be necessary to validate this prediction.

The model predicted that biomass of Halodule wrightii would have the most seasonal variability at the Fender Point Station compared to other sites, increasing to $>90 \mathrm{~g} / \mathrm{m}^{2}$ in winter and decreasing to $<1 \mathrm{~g} / \mathrm{m}^{2}$ in late fall (Fig. 11a). For H. wrightii, model predictions fell within the standard error of the mean biomass mea- 

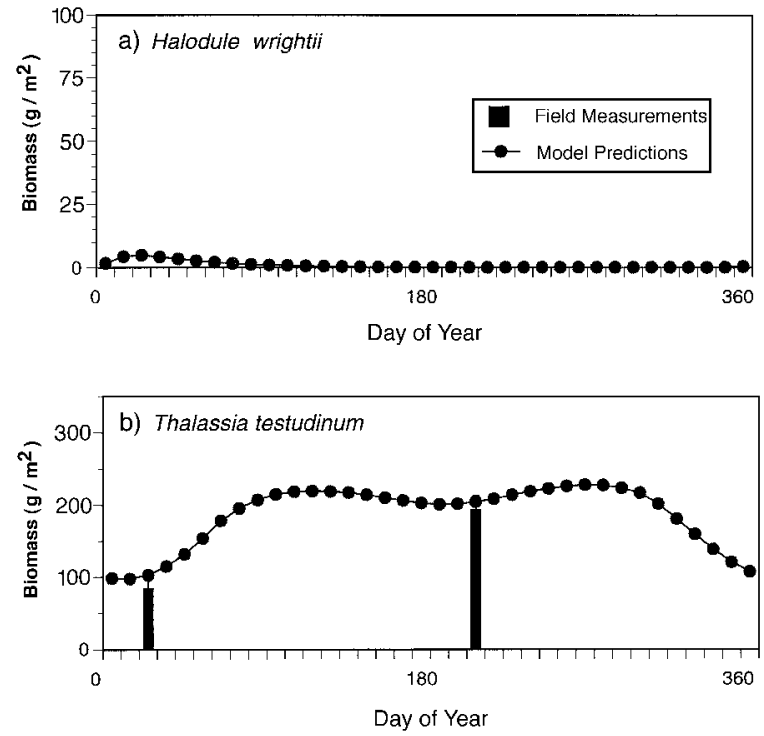

FIG. 10. Comparison of model predictions to field measurements at the Turkey Point station in Biscayne National Park.

sured in the field in both winter and summer at this location. Although more tolerant of the extremes in physical conditions found at this site (lower light, wider salinity range, higher sediment nutrients), $H$. wrightii was less able to sustain maximum productivity when total seagrass biomass was high. Thus, during spring and summer as light increased and seagrass biomass accumulated, $H$. wrightii became an inferior competitor.

Model predictions suggest that Thalassia testudinum would also have the greatest seasonal variability at this location, ranging from $\approx 20 \mathrm{~g} / \mathrm{m}^{2}$ in winter to a maximum of $>300 \mathrm{~g} / \mathrm{m}^{2}$ in summer (Fig. 11b). It was predicted that $T$. testudinum would have the greatest biomass in summer at Fender Point than in either of the other locations. Model predictions fell within the standard error of the field measurements in winter at this site. Although the model underpredicted biomass in summer, the mean field value for this site was the maximum found for all three sites in either season. It is possible that the upper limit for biomass-dependent productivity of $T$. testudinum is too high in the model (Fig. 1f). In the model, productivity of T. testudinum is not reduced until the total seagrass biomass is almost $300 \mathrm{~g} / \mathrm{m}^{2}$, and this validation result suggests that this relationship should be investigated more thoroughly.

The model predicts that Halodule wrightii will also undergo seasonal changes in abundance at Black Point, with maximum values in spring and fall and minimum values in summer (Fig. 12a). However, the reduction in biomass in summer is less than the comparable reduction at Fender Point. Physical conditions are even more extreme at Black Point due to its proximity to several inflowing canals and the prevailing tidal-influenced water circulation pattern (C. Rooth, personal
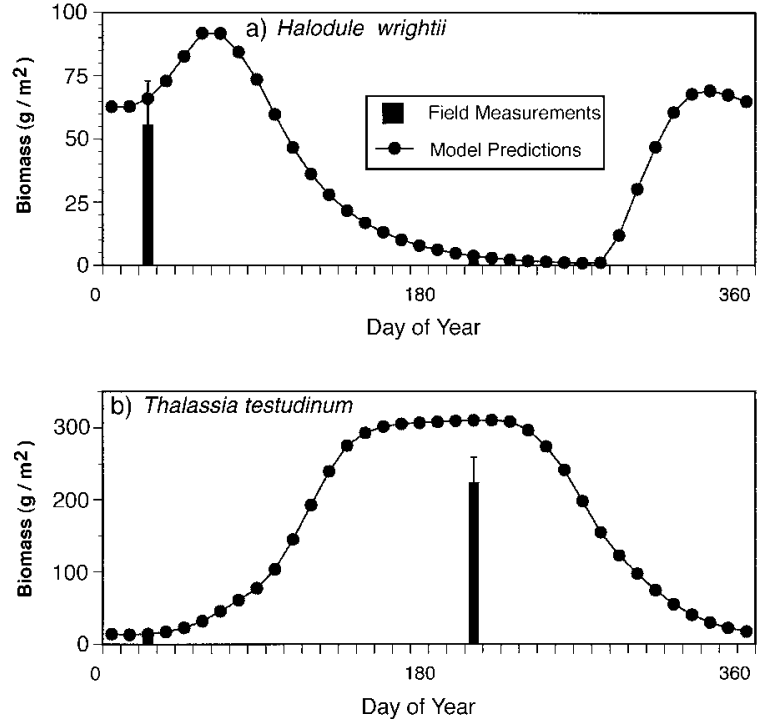

FIG. 11. Comparison of model predictions to field measurements at the Fender Point station in Biscayne National Park.

communication). Thus, productivity and subsequent biomass accumulation of Thalassia testudinum are never as high at Black Point as they are at Fender Point,releasing $H$. wrightii from biomass-related reductions in growth. Field measurements of $H$. wrightii in winter support the model predictions; the predicted biomass fell within the standard error of the observed mean. Biomass of $H$. wrightii in the field was lower in summer than in winter; however, the model overpredicted summer biomass measurements at this site. In addition, although the model predicted that $T$. testudinum would occur in low abundance in summer at this
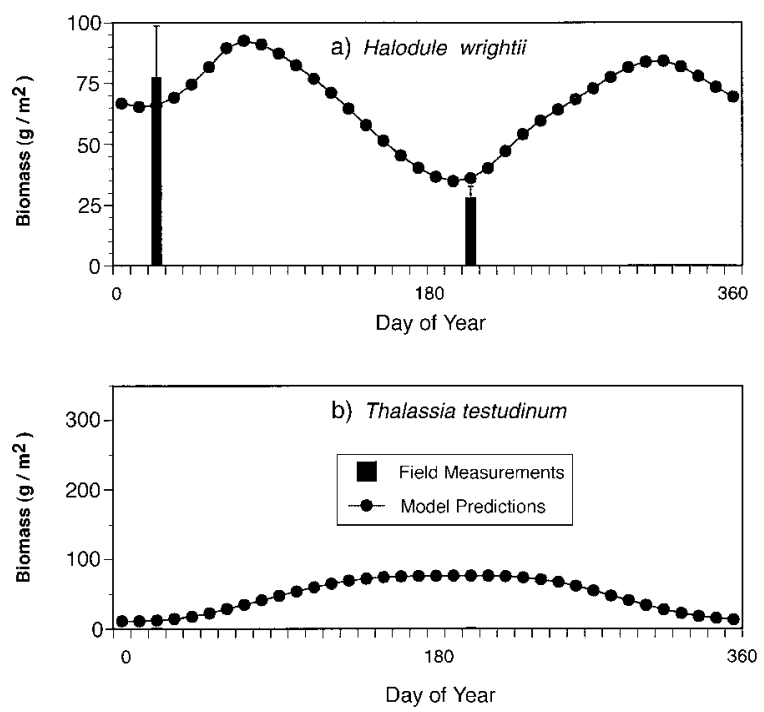

FIG. 12. Comparison of model predictions to field measurements at the Black Point station in Biscayne National Park. 
site, biomass measured in the field never exceeded 2 $\mathrm{g} / \mathrm{m}^{2}$ (Fig. 12b). This divergence of predicted and observed values may be due to several factors, including inaccuracies in the tolerances of T. testudinum to physical conditions and underestimation of the physical extremes at the Black Point site. Hydrodynamic models suggest that low salinity plumes may be very transient in this area (J. Wang, personal communication), so a monthly sampling regime (Nnaji 1987) may miss the true dynamics.

\section{CONCLUSIONS}

The model predicted temporal changes in seagrass community structure in areas with different environmental conditions relatively well. This means that in its present form it could be useful to managers to run what-if scenarios in order to make decisions about upstream water management practices, including allowable nutrients and freshwater diversion. There is a tremendous pressure on managers in South Florida to restore freshwater flows through the Everglades into Florida and Biscayne Bays. At present, these Bays are mostly marine embayments dominated by Thalassia testudinum, with estuarine areas dominated by Halodule wrightii restricted to a few hundred metres of canals. Predictions of this model suggest that there would be enormous changes in the seagrass communities with increasing freshwater influence, especially if the freshwater carried nutrients into the system. This model could be used as a tool in conjunction with a hydrological model to estimate the optimal quantity and quality of water that should be restored to these systems, as well as the rate that these changes should occur.

The results of this study suggest several areas that should be targeted for future research to improve the predictive capability of the model. First, under lownutrient conditions when water column and sediment $\mathrm{P}$ is limiting productivity of both seagrass and algae, physical conditions are very important factors controlling community structure. At present, there is relatively comprehensive information available on the light requirements of Thalassia testudinum and Halodule wrightii. However, there is less information on the individual effects of salinity and temperature on the growth rate of any of the seagrass species. This is especially true for separating the effects of differing timing and duration of alterations of these physical factors on growth and death.

Second, when nutrient supply is increased beyond limiting values, biological interactions such as shading by epiphytes become more important. This conclusion is supported by the increased sensitivity to epiphytes when nutrients are high and can be explained by the faster rates of growth, death, and turnover that are characteristic of these opportunistic forms of algae. With these life history traits, any changes due to enrichment are quickly and dramatically detectable. However, the parameters controlling growth and death rates of the algal groups, especially the epiphytes, are the least certain parameters in the model. In addition, the interaction between epiphyte abundance and light reduction is largely hypothetical, based on relationships derived for blocking of light due to epiphytes in temperate systems.

Last, the analyses presented in this paper suggest that the model formulation for biomass-dependent growth is very important in controlling the relative abundance of the three species of seagrass, regardless of nutrient conditions. Model output is very sensitive to changes in the ability of each seagrass species to grow under different levels of accumulated biomass. In the validation comparisons, seasonal changes in biomass of the dominant species of seagrass translated into changes in the subdominant. At present, competition for space is built into the model by incorporating a different growth capacity of each species of seagrass dependent on the sum of areal seagrass biomass. This simple formulation needs to be expanded to include competition for light, by including a biomass-dependent light reduction factor, or nutrients, by incorporating a dynamic nutrient cycling sector of the model.

ACKNOWLEDGMENTS

This research was funded, in part, by National Science Foundation grant number OCE-9-00649 to the University of Miami. Additional support was provided by the Elizabeth Ordway Dunn Foundation, and the Key Biscayne Rotary Club. Biscayne National Park provided boat and dive support. We thank Richard Curry, resource manager for BNP, for all his help and encouragement. We also thank the anonymous reviewers for their contribution to the final manuscript.

\section{Literature Cited}

Bendoricchio, G., G. Coffaro, and C. De Marchi. 1994. A trophic model for Ulva rigida in the Lagoon of Venice. Ecological Modelling 75/76:485-496.

Borum, J., L. Murray, and W. M. Kemp. 1989. Aspects of nitrogen acquisition and conservation in eelgrass plants. Aquatic Botany 35:289-300.

Cambridge, M. L., A. W. Chiffings, C. Brittan, L. Moore, and A. J. McComb. 1986. The loss of seagrass in Cockburn Sound, Western Australia. II. Possible causes of seagrass decline. Aquatic Botany 24:269-285.

Cambridge, M. L., and A. J. McComb. 1984. The loss of seagrass in Cockburn Sound, Western Australia. I. The time course and magnitude of seagrass decline in relation to industrial development. Aquatic Botany 20:229-243.

Caswell, H. 1979. The validation problem. Pages 296-308 in H. H. Shugart and R. V. O'Neill, editors. Systems ecology. Dowden, Hutchinson and Ross, Stroudsburg, Pennsylvania, USA.

Cebrián, J., N. Marbà, and C. M. Duarte. 1994. Estimating leaf age of the seagrass Posidonia oceanica (L.) Delile using the plastichrone interval index. Aquatic Botany 49: 59-65.

Costanza, R., and T. Maxwell. 1991. Spatial ecosystem modeling using parallel processors. Ecological Modelling 58: 159-183.

Costanza, R., F. H. Sklar, and M. L. White. 1990. Modeling coastal landscape dynamics. BioScience 40:91-107.

Duarte, C. M., N. Marbà, N. Agawin, J. Cebrián, S. Enríquez, M. D. Fortes, M. E. Gallegos, M. Merino, B. Olesen, K. Sand-Jensen, J. Uri, and J. Vermaat. 1994. Reconstruction of seagrass dynamics: age determinations and associated 
tools for the seagrass ecologist. Marine Ecology Progress Series 107:195-209.

Ebenhöh, W. 1994. Competition and coexistence: modelling approaches. Ecological Modelling 75/76:83-98.

Fong, P., and M. A. Harwell. 1994. Modeling seagrass communities in tropical bays and estuaries: a mathematical formulation of current hypotheses. Bulletin of Marine Science 54:757-781.

Jeltsch, F., and C. Wissel. 1994. Modelling dieback phenomena in natural forests. Ecological Modelling 75/76:111121.

Jørgensen, S. E. 1994. Models as instruments for combination of ecological theory and environmental practice. Ecological Modelling 75/76:5-20.

Kastner-Maresch, A. E., and H. A. Mooney. 1994. Modelling optimal plant biomass partitioning. Ecological Modelling 75/76:309-320.

Kitano, T., M. Okumura, and M. Idogak. 1978. Uptake of phosphate ion by calcium carbonate. Geochemical Journal 12:29-37.

Larkum, A. W. B., A. J. McComb, and S. A. Shepard. 1989 Biology of seagrasses: a treatise on the biology of seagrass with special reference to the Australian region. Elsevier, Amsterdam, New York, New York, USA.

Littler, M. M., and D. S. Littler. 1980. The evolution of thallus form and survival strategies in benthic marine macroalgae: field and laboratory tests of a functional form model. American Naturalist 116:25-44.

Mankin, J. B., R. V. O’Neill, H. H. Shugart, and B. W. Rust. 1979. The importance of validation in ecosystem analysis Pages 309-317 in H. H. Shugart and R. V. O'Neill, editors. Systems ecology. Dowden, Hutchinson and Ross, Stroudsburg, Pennsylvania, USA.

Miller, D. R. 1974. Sensitivity analysis and validation of computer simulation models. Journal of Theoretical Biology 48:345-360.

. 1979. Model validation through sensitivity analysis Pages 292-295 in H. H. Shugart and R. V. O'Neill, editors. Systems ecology. Dowden, Hutchinson and Ross, Stroudsburg, Pennsylvania, USA.

Miller, D. R., D. E. Weidhaas, and R. C. Hall. 1973. Parameter sensitivity in insect population modelling. Journal of Theoretical Biology 42:263-274.

Morse, J. W., J. J. Zullig, R. L. Iverson, G. R. Choppin, A.
Mucci, and F. J. Millero. 1987. The influence of seagrass beds on the chemistry of coarse-grained sediments in the Bahamas. Marine Chemistry 22:71-83.

Nnaji, S. 1987. South Biscayne Bay water quality: a twelve year record for Biscayne National Park. U.S. Department of the Interior, National Park Service, Southeast Regional Office, Atlanta, Georgia, USA.

Pedersen, M. F., and J. Borum. 1993. An annual nitrogen budget for a seagrass Zostera marina population. Marine Ecology Progress Series 101:169-177.

Popper, K. 1959. The logic of scientific discovery. Basic Books, New York, New York, USA.

. 1962. Conjectures and refutations: the growth of scientific knowledge. Basic Books, New York, New York, USA.

Powell, G. V. N., W. J. Kenworthy, and J. W. Fourqurean. 1989. Experimental evidence for nutrient limitation of seagrass growth in a tropical estuary with restricted circulation. Bulletin of Marine Science 44:324-340.

Pulich, W. M., and W. A. White. 1991. Decline of submerged vegetation in the Galveston Bay system: chronology and relationships to physical processes. Journal of Coastal Research 7:1125-1138.

Reyes, E., and M. Merino. 1991. Diel dissolved oxygen dynamics and eutrophication in a shallow, well-mixed tropical lagoon (Cancun, Mexico). Estuaries 14:372-381.

Robblee, M. B., T. R. Barber, P. R. Carlson, Jr., M. J. Durako, J. W. Fourqurean, L. K. Muehlstein, D. Porter, L. A. Yarbro, R. T. Zieman, and J. C. Zieman. 1991. Mass mortality of the tropical seagrass Thalassia testudinum in Florida Bay (USA). Marine Ecology Progress Series 71:297-299.

Short, F. T., M. W. Davis, R. A. Gibson, and C. F. Zimmermann. 1985. Evidence for phosphorus limitation in carbonate sediments of the seagrass Syringodium filiforme. Estuarine and Coastal Shelf Science 20:419-430.

Short, F. T., W. C. Dennison, and D. G. Capone. 1990. Phosphorus-limited growth of the tropical seagrass Syringodium filiforme in carbonate sediments. Marine Ecology Progress Series 62:169-174.

Silberstein, K., A. W. Chiffings, and A. J. McComb. 1986. The loss of seagrass in Cockburn Sound, Western Australia. III. The effect of epiphytes on productivity of Posidonia australis Hook.F. Aquatic Botany 24:355-371.

Tomovic, R., and M. Vukobratovic. 1972. General sensitivity theory. American Elsevier, New York, New York, USA. 